\title{
Ascorbic Acid Content of Some Malpighia spp. ${ }^{1}$
}

\author{
George C. Jackson ${ }^{2}$ \\ INTRODUCTION
}

Since the reporting of the high ascorbic acid content of the West Indian Cherry by Asenjo and Freire de Gúzman $(4)^{3}$, and verification by Mustard (40), literature search indicates that Malpighia punicifolia L. $(1,2,3,5,6,7,8$, $9,10,14,15,16,17,19,20,21,22,24,25,26,27,28,29,32,33,34,35,41,42,44,45)$ and the closely allied species, $M$. glabra L. $(15,16,23,30,31,32,39,38,39,40,45,46$, $.77)$ have received much attention.

Of this genus Malpighia, which consists of possibly 40 species (11), the vitamin $\mathrm{C}$ content of only 2 species, other than those mentioned above, has been reported previously, i.e., M. coccigera L., by Mustard (40), from Florida, and $M$. souzae by Miranda (.37), from Mexico.

\section{PROCEDURE AND RESULTS}

Partly ripe fruit were collected from shrubs of five Malpighia species maintained in the collection at the Substation at Isabela, P.R., and the ascorbic acid content was determined by the iodometric method of Ballenline (12). The results were as follows:

1. M. Shaferi Britton \& Wilson, $507 \mathrm{mg} . / 100 \mathrm{gm}$. of edible matter.

2. $M /$ infestissima (A. Juss.) Rich., $153 \mathrm{mg} . / 100 \mathrm{gm}$. of edible matter.

3. $M$. linearis Jac(., $139 \mathrm{mg}$. $/ 100 \mathrm{gm}$. of edible matter.

4. M. coccigera $\mathrm{L}$., $103 \mathrm{mg}$. $/ 100 \mathrm{gm}$. of edible matter.

5. M. suberosa Small, $29 \mathrm{mg} . / 100 \mathrm{gm}$. of edible matter.

\section{DIscussiox}

The five species of Malpighia reported on herein are described elsewhere in the literature $(13,18,36,43)$. None of the species tested and presented here approached the previously published ascorbic acid minimums for $M$. punicifolia L., M. glabra L., or M. souzae. However, Munsell et al. $(38,39)$ reported that $M$. glabra L. from Guatemala yielded 14.9 and $15.5 \mathrm{mg}$. of ascorbic acid per $100 \mathrm{gm}$. of edible matter. Carvioto $(1 \bar{j})$, also reported M. glabra L. from Mexico as yiclding 125.0 $\mathrm{mg}$. of ascorbic acid per 100 gm. of edible matter.

1 Submitted for publication Jan. 10, 1913.3.

2 Assistant Horticulturist, Fruit Experiment Substation, Fortuna, P.R. The author wishes to express his thanks to Mr. A. Pérez López, Research Assistant, Isabela Substation, Isabela, P.R., and to the staff, Central Analytical Laboratory, Agricultural Experiment Station, Río Piedras, P.R., for their assistance in this paper.

3 Italic numbers in parentheses refer to literature Cited, pp, 202-4. 
The $M$. coccigera L. fruit tested yielded more ascorbic acid than the same species reported by Mustard (40) from Florida, which yielded 64 to $74 \mathrm{mg}$. of ascorbic acid per $100 \mathrm{gm}$. of edible matter.

\section{CONCLUSION}

Of a genus consisting of possibly 40 species, and of which only 8 have been reported upon, M. punicifolia L, M. glabra L., and M. souzae still yield the most natural ascorbic acid.

\section{SUMMARY}

Malpighia Shaferi Britton \& Wilson, M. infestissima (A. Juss.) Rich., $M$. linearis Jacq., M. coccigera L., and M. suberosa Small are reported to contain $507,153,139,103$, and $29 \mathrm{mg}$. of ascorbic acid per $100 \mathrm{gm}$. of edible matter, respectively.

\section{RESUM EN}

De acuerdo con los datos a mano, Malpighia Shaferi Britton \& Wilson, M. infestissima ( $\Lambda$. Juss.) Rich., M. linearis Jac(. M. coccigera L., and $M$. suberosa Small, contienen 507, 153, 139, 103, y 29) mg. de ácido ascórbico por cada $100 \mathrm{gms}$. de material comestible, respectivamente.

\section{LITERA'TURE CI'TEI)}

1. Aróstegui, F., Asenjo, C. F. Muñiz, Ana I., and Alemany L., Studies on the West Indian cherry, Malpighia punirifolia L.; Obscrvations and data on a promising selection, Proc. Fla. Stale Hort. Soc. 67 250-5, 1954.

2. - Studies on the Indian Cherry, Malpighia punirifolia L.: (Observations and Data on a Promising Selection, Tex. Avocado Soc. Ybk. 37-42, 1954.

3.-- Observations and data on a promising selection of the West Indian cherry, (Malpighia punicifolia L.), J. Agr. Univ. P.R. $\$ 9$ (2) 51-6, 1955.

4. Asenjo, C. F., and Freire de Cimmán, A. R., Lat acerola mojor que la guayaba, Nulricion al Dia. p. 82, 1945.

5. - - - - , High ascorbic acid content of the West Indian cherry, Sci. 105219 , 1946.

6. Asenjo, C. F., and Moscoso, C. (i., The ascorbic acid content and other characteristics of the West Indian cherry, Food Res. 15 (2) 103-6, 1950.

7. Asenjo, C. F., Composición química do las principales frutas de las Antillas, Rev, de A fr. P.R. 43 (1) 282-8, 1952.

8. - - The story of the West Indian cherry (Malpighia punicifolin I..), Bol. ('ol. Quimicu $108-11.1953$.

9. - Aspectos químicos y nutritivos de la acerola (Malpighia punicifolia I.), Cienria $19(6 / 7)$ 109-18, 1959.

10. - - Vitamin C in acerola and rose hip, J. Agr. Cniv. P.R. 43 (3) 212-3, 1959.

11. Bailey, L. H., Revised Manual of Cultivated Plants, Macmillan Co., New York, N.Y., pp. (6+1, 194!).

12. Ballentine, R., Determination of ascorbic acid in citrus fruit juices, Ind. Eng. ('hem. Anal. Ed. 13 (2) 89, 1941. 
13. Britton, N. L., and Wilson, P., Scientific survey of Porto Rico and the Virgin Islands, N.Y. Acad. Sci. 5 (1) 442-5, 1923.

14. Campillo, A. del, and Asenjo, C. F., The distribution of ascorbic acid deliydroascorbic acid and diketogulonic acid in the acerola fruit at different stages of development, J. Agr. Univ. P.R. 41 (3) 161-6, 1957.

15. Carvioto, R. E., Valor nutritive de los alimentos Mexicanos, Ciencia 11 9-17, 1950.

16. Carvioto, R. E., Massieu H., G., Gúzman G., G., and Calvo de la Torre, J., Composición de alimentos Mejicanos, Ciencia 11 129-55, 1951.

17. Derse, P. F., and Elvehjem, C. A., Nutrient content of acerola, a rich source of vitamin C. J. Am. Med. Assoc. 156 (16) 1501, 1954.

18. Fawcett, W., and Rendle, A. B., Flora of Jamaica, Brit. Mus. Nat. Hist. 4 (2) $224-9,1920$.

19. Fitting, K. O., and Miller, C. D., Variation in the ascorbic acid content of in dividual fruits of the acerola, Hawaii Farm Sci. 7 (2) 7, 1958.

20. - Stability of ascorbic acid in frozen and bottled aceroln juice and combined with other fruit juices, Food Res. 26 203-10, 1960.

21. Floch, H., and Lecuillen, A., Enquete sur la Consommation alímentaire réelle et la Valeur alimentaire de la Ration Guayanise, III, Analyes de Produits alimentaires Guyanais, Arch. Inst. Pasteur Guyane Fr., Publ. 285, 1953.

22. Floch, H., and Gelard, A. M., La Cerise ronde de Cayenne, Malpighia punicifolia L., la Richesse exceptionelle en Vitamine C, Arch. Inst. Pasteur Guyane Fr., Publ. 368, 1955.

23. Floch, H., Dosage de l'Acide Ascorbique dans les Fruts Guyanaises, Arch. Inst. Pasteur Guayne Fr., Publ. 392 205-7, 1956.

24. - - A propos de la "Cerise de Antilles" (Malpighia punicifolia L.) et ses proprietes alimentaires, Qualitas Plant et Mater. Veg. 3 (4) 178-82, 1958.

25. Giral, F., La acerola (M. punicifolia) de Puerto Rico, Ciencia 14 279-80, 1954.

26. Hernández Medina, E., and Vélez Santiago, J., Response of the acerola (Malpighia punicifolia L.) to the application of lime and foliar sprays of magnesium and minor elements, Proc. Carib. Reg. Am. Soc. Hort. Sci. 4 20-5, 1960.

27. Jackson, G. C., and Pennock, W., Fruit and vitamin C production of 5- and 6year-old acerola trees, J. Agr. Univ. P.R. 42 (3) 196-205, 1958.

28. Jaffe, W. G., Budowski, P., and Gorra, C., Estudio sobre el contenido de acido ascórbico (vitamina C) en las principales frutas de Venezuela, Arch. Venezolano de Nutrición 1 83-106, 1950.

29. Landrau, P., Jr., and Hernández Medina, E., Effects of major and minor elements, lime, and soil amendments on yield of ascorbic acid content of acerola ( $\mathrm{Mal}$ pighia punicifolia L.), J. Agr. Univ.P.R. 43 (1) 19-33, 1959.

30. Ledin, R. B., The West Indian or Barbados Cherry, Univ. Fla. Sub-Trop. Exp. Sta., Misc. Rep. 56-1, 1955.

31. - A report on improvement of subtropical fruits at the Sub-Tropical Experiment Station, Homestead, Fla., Ceiba 4 (5) 275-85, 1955.

32. - A comparison of three clones of Barbados cherry and the importance of improved selections for commercial plantings, Proc. Fla. Stale Hort. Soc. 69 293-6, 1956.

33. Leme, J. Jr., A vitamin C. em algumas plantas brasileira e exoticas, Rev. Agric. (Piracicaba) 26 (9/10) 319-30, 1951.

34. Massieu, H., G., Ruiz Quiles, A., and Cravioto, R. O., Nuevos datos sobre el contenido de vitamina C de Malpighia Punicifolia L., procedente de Yucatán, Ciencia (Mexico) 15 (9/10) 206-7, 1953. 
35. Moscoso, C. G., West Indian cherry-richest known source of natural vitamin C, Econ. Bot. 10 (3) 280-94, 1956.

30. Moscoso, R. M., Catalogus Florae Domengensis, 1 289-97, 1943.

37. Miranda, F., Dos arbustos notables del estado de Yucatán, Soc. Bot. de Mex. 21 8-14, 1957.

38. Munsell, H. E., Williams, L. O., Guild, L. P., Troescher, C. B., Nightengabe, G., and Harris, R. S., Composition of food plants of Central America III, Guatemala, Food Res. 15 34-52, 1950.

39. Munsell, H. E., Williams, L. O., Guild, L. P., Kelly, L. T., McNally, Ann M., and Harris, R. S., Composition of food plants of Central America VIII, Guatemala, Food Res. 15 439-53, 1950.

40. Mustard, Margaret J., The ascorbic acid content of some Malpighia fruits and jellies, Sci. 104 230-1, 1946.

41. - Ascorbic acid content of some miscellaneous tropical and subtropical plant products, Food Res. 17 (1) 31-5, 1952.

42. Ponce de León, A., El cerezo de las Antillas (Malpighia punicifolia L.), Soc. Cubana Bot. Rev., 12 53-4, 1955.

43. Sauget, J.S. (Hermano León, F.S.C.), and Liogier, E. E. (Hermano Alain, F.S.C.) Flora de Cuba, 3 17-24, 1953.

44. Singh Dhaliwal, T. and Torres Sepúlveda, A., Performance of acerola, Malpighia punicirfolia $\mathrm{L}$. in the coffee region of Puerto Rico, J. Agr. Univ. P.R., 46 (3) 195-204, 1962.

45. Stahl, A. J., Kaplow, M., and Nelson, R., The present status and future possibilities of Barbados cherries, Proc. Fla. State Hort. Soc. 68 138-43, 1955.

46. Vieta de Ruiz, E., Duran, O., Rozenkrantz, J., and Kaufman, E., Contenido de vitamina $\mathrm{C}$ en frutas Cubanas, Inform. Med. 10 160-5, 1946.

47. Yamane, G. M., and Nakasone, H. Y., Pollination and fruit set studies of the acerola Malpighia Glabra L. in Hawaii, Proc. Am. Soc. Hort. Sci. 78 141-8, 1961. 